\title{
How to Teach Morality - Georg Lind (Review)
}

\author{
Semíramis Llanos Cobos \\ (Santiago de Chile, semiramis.llanoscobos@gmail.com)
}

\begin{abstract}
Review of: Georg Lind (2016) How to teach Morality. Promoting Deliberation and Discussion, Reducing Violence and Deceit, pp. 200, Berlin: Logos Verlag
\end{abstract}

In his new book "How to teach Morality," Georg Lind, a German educational psychologist, researcher and academic, tells us about morality - clearly, with detail and accuracy, in an easy to follow language. It is a wonderful book about a topic of a huge relevance today. He shares with the readers his knowledge, experience and research on a subject to which he passionately dedicated his whole life.

What does morality mean? Is it important? Why? How we can make good moral decisions on our own? He reports studies which show that on one hand a large percentage of people has an low level of moral competence, but on the other hand the moral difficulties steadily increase because of the development of science and technology, of social changes, growing social injustice, globalization, IT revolution and so on. Hence while our life becomes more and more complicated, we face more and more situations in which do not know what is right and wrong.

Lind argues that morality must be fostered as much as is possible. For this he developed a specific method, the Konstanz Method of Dilemma Discussion ${ }^{\circledR}\left(\mathrm{KMDD}^{\circledR}\right)$. It is a well-tested method for promoting moral development in children and adults. The KMDD ${ }^{\circledR}$ is a new instrument. It affects people internally, promoting their ability to reason and make decisions on the basis of moral principles. In healthcare the $\mathrm{KMDD}^{\circledR}$ can contribute to improve the doctor-patient relationship (healthcare team-patient), and the ability of doctors to make appropriate and timely decisions in complex, dilemmatic situations. Moral competence - through its social-communicative face -- is also a fundamental and powerful basis of democracy.

Step by step, Lind describes his theory of moral behaviour and development, its meaning and theoretical background. He also informs about the philosophical and ethical roots of his theory, beginning with Socrates, Baruch Spinoza, Immanuel Kant, John Dewey, and Jürgen Habermas. His and other authors' multiples research provide the empirical fundament of his approach.

Lind had also developed a measuring instrument of moral competence, the Moral Competence $\mathrm{Test}^{\circledR}\left(\mathrm{MCT}^{\circledR}\right)$. It has been translated in many languages, 
and has been validated in several countries. It is designed to evaluate the efficacy of methods and programs of moral education through experimental pre-test and post-test designs.

Moral competence is relevant for responsibility-taking, autonomy, critical thinking, and discussion ability. As Lind reports in his book, experiments show that an insufficient development of moral competence leads to wrong behaviour, causes harm to others, increases conflict and violence. Thus there is an urgent need to teach moral competence.

By promoting moral competence, the KMDD ${ }^{\circledR}$ would allow greater humanization in many areas of our activities, as well as progress of democracy - an issue of major importance in our world. 
Semíramis Llanos Cobos

(Santiago de Chile, semiramis.llanoscobos@gmail.com)

\title{
How to Teach Morality - Georg Lind (Review)
}

\begin{abstract}
In his recent book, Georg Lind develops the philosophical and methodological foundations of the Konstanz Method of Dilemma Discussion ${ }^{\circledR}$, which provide both theoretical and practical work frames for developing moral and democratic competencies.
\end{abstract}

Keywords: Georg Lind, Konstanz Method of Dilemma Discussion, Moral ist Lehrbahr, How to Teach Morality

Ethics in Progress (ISSN 2084-9257). Vol. 7 (2016). No. 1, Art. \#20, pp. 319-321.

doi: 10.14746/eip.2016.1.17 